\title{
UPAYA MENINGKATKAN KETERAMPILAN PROSES SAINS MELALUI METODE PRAKTIKUM BERBASIS MODIFIED FREE INQUIRY (MFI) PADA KONSEP ANIMALIA DI KELAS X MIPA
}

\author{
Mila H. Catria Marta ${ }^{1}$, Ondi Suganda ${ }^{2}$, Rahma Widiantie ${ }^{3)}$ \\ ${ }^{1}$ Mahasiswa Program Studi Pendidikan Biologi FKIP, Universitas Kuningan \\ Email: milahadriyaticatria@yahoo.com \\ 23 Dosen Program Studi Pendidikan Biologi FKIP, Universitas Kuningan \\ Email: rahma.widiantie@uniku.ac.id
}
APA Citation: Marta, M. H. C., Suganda, O., \& Widiantie, R. (2018). Upaya Meningkatkan Keterampilan Proses Sains Melalui Metode Praktikum Berbasis Modified Free Inquiry (MFI) Pada Konsep Animalia Di Kelas X MIPA. Quagga: Jurnal Pendidikan dan Biologi, 10(1), 1-9. doi: 10.25134/quagga.v10i01.802.

\begin{abstract}
Abstrak: Keterampilan proses sains berpotensi membangun kompetensi dasar hidup siswa dalam bersikap ilmiah dan proses konstruksi pengetahuan secara bertahap. Siswa cenderung kurang terampil dalam mengamati, merumuskan masalah, membuat hipotesis, merancang percobaan, melakukan percobaan, hingga membuat kesimpulan dalam mengkaji fenomena sains yang telah difasilitasi dalam pembelajaran. Penelitian ini bertujuan untuk menganalisis penerapan metode praktikum berbasis Modified Free Inquiry (MFI) dalam meningkatkan keterampilan proses sains siswa pada konsep Animalia di Kelas X MIPA SMA Negeri di Kuningan. Jenis penelitian yang digunakan adalah dengan desain non equivalent control group design. Subjek dalam penelitian ini adalah siswa kelas X MIPA 1 sebagai kelas eksperimen dan kelas X MIPA 4 sebagai kelas kontrol. Pengumpulan data dilakukan dengan menggunakan instrumen soal tes, asesmen kinerja dan lembar observasi. Hasil penelitian pada postest menunjukkan bahwa nilai signifikasi antara kelompok eksperimen dengan kelompok kontrol

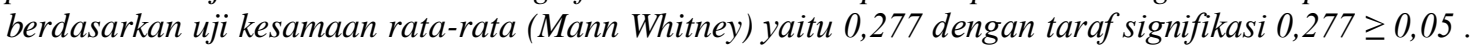
Hal tersebut menyimpulkan tidak terdapat perbedaan peningkatan keterampilan proses sains antara kelas eksperimen dan kelas kontrol. Hal serupa dengan perhitungan uji n-gain yang memiliki nilai 0,284 dengan taraf signifikasi 0,284 20,05 yang menunjukkan bahwa peningkatan keterampilan proses sains di kelas eksperimen dan kelas kontrol tidak jauh beda. Hal tersebut dapat disimpulkan bahwa tidak terdapat perbedaan metode praktikum yang berbasis Modified Free Inquiry maupun metode praktikum yang berbasis Group Investigation dalam meningkatkan keterampilan proses sains pada pembelajaran Biologi, materi Animalia. Guru dapat menggunakan model pembelajaran Modified Free Inquiry maupun Group investigation dalam praktikum untuk meningkatkan keterampilan proses sains siswa.
\end{abstract}

Kata kunci : keterampilan proses sains, metode praktikum, model Modified Free Inquiry

\begin{abstract}
Science process skills have the potential to build the basic competence of the students in a scientific attitude and knowledge construction process gradually. Students has less skilled in observing, formulating problems, making hypotheses, designing experiments, experimenting, and to making conclusions in studying the phenomenon of science that has been facilitated in learning. The purpose of this research are to analysis application practicum method, Modified Free inquiry based to improve science process skill to student on the concept Animal in Class of X MIPA SMAN Kuningan. Type of this research used with Nonequivalent Control Group Design.Subject in this research is X MIPA 1 as a experiment class and X MIPA 4 as a control class. The data was collected using test science process skill, performance assessment, and observation sheet for science process skill. The result of the research based of average equality test (Mann Whitney) on posttest shows that the significance value between the experimental group and the control group is 0,277 $\geq 0,05$. It can be conclude from the data analysis that there is no difference in the increase in the science process skills between the experimental class and the control class. That same of $n$-gain test that has a value of 0.284 with a significance level of $0.284 \geq 0.05$ which shows that the improvement of science process skills in the experimental class and control classes is not much different. It can be concluded that there is no difference of practicum method based on Modified Free Inquiry or practicum method based on Group Investigation in improving science process skill in Animal concept. The student can be used Modified Free Inquiry model and Group Investigation model in class of practice to improve science process skill.
\end{abstract}

Keywords : Modified Free Inquiry, practicum method, science process skill 
Quagga: Jurnal Pendidikan dan Biologi Volume 10, Nomor 1, Januari 2018

\section{PENDAHULUAN}

Pembelajaran dengan pendekatan saintifik menegaskan bahwa siswa diajak untuk bekerja sains, dalam artian siswa diberi keleluasaan untuk terampil dalam proses ilmiah. Dari mulai kegiatan siswa dalam mengamati fenomena ilmiah, mengamati permasalahan yang ada sampai pada tahap menyimpulkan fenomena tersebut. Sehingga membuat siswa dalam mendapat konsep pembelajaran di kelas, siswa bukan lagi melakukan kegiatan menghafal akan tetapi lebih pada kegiatan berpikir. Hal tersebut menegaskan jika pendekatan saintifik merupakan pendekatan yang semua aspeknya terintegrasi pada proses metode ilmiah dan diterapkan melalui keterampilan proses. Keterampilan proses tersebut menurut pendapat Septi (2015:1) adalah keterampilan proses sains yang diterapkan kepada siswa untuk melakukan penyelidikan ilmiah..

Keterampilan proses sains berpotensi membangun kompetensi dasar hidup siswa melalui pengembangan keterampilan sains, sikap ilmiah, dan proses konstruksi pengetahuan secara bertahap. Sehingga dalam pembelajaran berlangsung siswalebih menguasai konsep sains dibandingkan dengan menghafal konsep sains, karena pada hakikatnya jika kita lebih mengusai konsep sains siswa akan lebih mudah memahami karena telah mendapatkan konsepnya secara mandiri melalui keterampilan proses sains dalam membuktikan rasa ingin tahumya ketika dihadapkan oleh guru mengenai fenomena berbasis sains. Pembelajaran inquiry merupakan pembelajaran pembuktian dari rasa ingin tahu siswa terhadap suatu fenomena berbasis sains.

Berdasarkan pengalaman peneliti selama kegiatan PPL (Praktik Pengalaman Lapangan) SMA Negeri Kuningan yang terakreditasi, siswa cenderung belajar di kelas secara teoritis dengan pembelajaran konvensional saja tanpa menerapkan kegiatan saintifiknya melalui keterampilan proses sains. Hampir $100 \%$ di setiap konsep pembelajaran Biologi yang dipelajari tiap Bab nya siswa kurang diperkenalkan prinsip kerja laboratorium untuk melakukan keterampilan proses sains. Peran guru dalam hal ini kurang mefasilitasi siswa untuk diajak kerja sains, sehingga siswa kurang terampil dalam menguasai konsep
p-ISSN 1907-3089, e-ISSN 2651-5869

https://journal.uniku.ac.id/index.php/quagga

sains. Rata-rata siswa kelas X MIPA menganggap pembelajaran sains itu sulit, terlebih pada mata pelajaran Biologi yang dianggap banyak menyajikan nama-nama ilmiah yang sulit dipahami. Selain itu, siswa cenderung kurang terampil dalam mengamati, merumuskan masalah, membuat hipotesis, merancang percobaan, melakukan percobaan, hingga membuat kesimpulan fenomena sains yang disajikan oleh guru.

Salah satu cara untuk mengatasi permasalahan tersebut adalah dengan menerapkan model pembelajaran Modified Free Inquiry (MFI). Dalam pelaksanaan pembelajaran $M F I$ siswa diberi kebebasan dalam merencanakan praktikum. Guru hanya berperan sebagai konsultan dalam memberikan bantuan yang dibutuhkan siswa untuk melakukan rancangan percobaan. Model Inquiri Bebas Termodifikasi merupakan salah satu tingkatan inquiri berdasarkan variasi bentuk keterlibatannya dan intensitas keterlibatan siswa untuk mengatasi masalah dan melakukan proses penyelidikan.

\section{METODOLOGI PENELITIAN}

Metode penelitian yang digunakan dalam penelitian ini adalah metode Quasi eksperimental sedangkan desain yang digunakan adalah non equivalent control group design. (Sugiyono, $2014: 107)$.

Penelitian dilaksanakan dari mulai 17 April sampai 3 Mei 2017 yang dilaksanakan pada Semester Genap Tahun Ajaran 2016/2017 di kelas X MIPA SMA Negeri di Kuningan yang terakreditasi.

Praktikum di laboratorium pula dapat meningkatkan keterampilan proses sains siswa karena dirinya akan memiliki sensasi menjadi seorang ilmuan. Senada dengan pernyataan Rustaman (2005:135) dalam Vindri et al. (2014:1) praktikum merupakan kegiatan pembelajaran yang bertujuan agar siswa mendapat kesempatan untuk menguji dan mengaplikasikan teoridengan menggunakan fasilitas laboratorium maupun di luar laboratorium. Praktikum dalam pembelajaran Biologi merupakan metode yang efektif untuk mencapai tujuan pembelajaran. Berdasarkan uraian di atas maka penulis akan melakukan penelitian dengan judul "Upaya Meningkatkan 
Quagga: Jurnal Pendidikan dan Biologi Volume 10, Nomor 1, Januari 2018

Keterampilan Proses Sains melalui Metode Praktikum Berbasis Modified Free Inquiry (MFI) pada Konsep Animalia di Kelas X MIPA"

Adapun yang menjadi pokok permasalahan dalam penelitian ini adalah upaya meningkatkan keterampilan proses sains melalui metode praktikum berbasis Modified Free Inquiry pada Konsep Animalia di kelas X MIPA. Tujuan penelitian ini adalah menganalisis penerapan metode praktikum berbasis Modified Free Inquiry (MFI) dalam meningkatkan keterampilan proses sains siswa pada konsep Animalia di Kelas X MIPA SMA Negeri 1 Kuningan tahun ajaran 2016/2017.

Jumlah populasi kelas X MIPA adalah 200 siswa. Teknik pengambilan sampel yang digunakan adalah Cluster Random Sampling, dan sampel yang dipilih yaitu 2kelas. Kelas X MIPA 1 sebagai kelas eksperimen yang dalam pembelajarannya menggunakan metode praktikum berbasis Modified Free Inquiry dan kelas X MIPA4 sebagai kelas kontrol dalam pembelajarannya menggunakan metode praktikum berbasis Group Investigation.
p-ISSN 1907-3089, e-ISSN 2651-5869

https://journal.uniku.ac.id/index.php/quagga

Penelitian ini menggunakan tiga instrumen untuk pengambilan data yaitu lembar observasi yang digunakan untuk mengamati keterlaksanaan guru dalam mengarahkan siswa dengan model Modified Free Inquiry, asesmen kinerja digunakan untuk mengukur keterampilan proses sains siswa saat melangsungkan praktikum dan tes uraian digunakan untuk mengetahui peningkatan keterampilan proses sains siswa setelah melaksanakan praktikum berbasis Modified Free Inquiry.

\section{HASIL DAN PEMBAHASAN Analisis Keterampilan Proses Sains}

Soal uraian yang telah dibuat untuk mengetahui sejauh mana keterampilan proses sains siswa dalam pembelajaran Biologi khususnya materi Animalia berdasarkan indikator Keterampilan Proses Sains yang meliputi mengamati, mengklasifikasi, berkomunikasi, berhipotesis dan menerapkan konsep/prinsip. Setiap soal uraian dimuat berdasarkan indikator-indikator tersebut. Persentase Keterampilan Proses Sains Siswa dapat dilihat pada tabel 1 di bawah ini:

Tabel 1. Rata-rata dan Persentase Keterampilan Proses Sains (Pretest)

\begin{tabular}{cccccc}
\hline \multirow{2}{*}{ No } & Indikator KPS & $\begin{array}{c}\text { Skor } \\
\text { Rata-rata }\end{array}$ & $\begin{array}{c}\text { Kelas } \\
\text { Eksperimen }\end{array}$ & $\begin{array}{c}\text { Skor } \\
\text { Rata-rata }\end{array}$ & $\begin{array}{c}\text { Kelas } \\
\text { Kontrol }\end{array}$ \\
\cline { 4 - 5 } $\mathbf{1}$ & Mengamati & 1,1 & 42 & 1,0 & Persentase \\
\hline $\mathbf{2}$ & Mengklasifikasi & 0,8 & 35 & 0,7 & 34 \\
\hline $\mathbf{3}$ & Berkomuni kasi & 1,2 & 44 & 0,9 & 37 \\
\hline $\mathbf{4}$ & Berhipotesis & 0,9 & 37 & 0,8 & 35 \\
\hline $\mathbf{5}$ & $\begin{array}{c}\text { Menerapkan } \\
\text { Konsep }\end{array}$ & 1,3 & 46 & 1,2 & 44 \\
\hline & Rata-rata & $\mathbf{1 , 0 6}$ & $\mathbf{4 0 , 8}$ & $\mathbf{0 , 9 2}$ & $\mathbf{3 8}$ \\
\hline
\end{tabular}

Berdasarkan tabel $1 \mathrm{di}$ atas menunjukkan rata-rata keterampilan proses sains. Rata-rata keseluruhan pada saat pretest, di kelas eksperimen terhitung 1,06 sedangkan di kelas kontrol terhitung 0,92 . 
Tabel 2.Rata-rata dan Persentase Keterampilan Proses Sains (Posttest)

\begin{tabular}{clcccc}
\hline No & Indikator KPS & $\begin{array}{c}\text { Skor } \\
\text { Rata-rata }\end{array}$ & $\begin{array}{c}\text { Kelas } \\
\text { Eksperimen } \\
\text { Persentase }\end{array}$ & $\begin{array}{c}\text { Skor } \\
\text { Rata-rata }\end{array}$ & $\begin{array}{c}\text { Kelas } \\
\text { Kontrol } \\
\text { Persentase }\end{array}$ \\
\hline $\mathbf{1}$ & Mengamati & 2,0 & 70 & 2,0 & 70 \\
\hline $\mathbf{2}$ & Mengklasifikasi & 1,7 & 61 & 1,6 & 56 \\
\hline $\mathbf{3}$ & Berkomuni kasi & 1,8 & 63 & 1,7 & 59 \\
\hline $\mathbf{4}$ & Berhipotesis & 1,6 & 56 & 2,0 & 70 \\
\hline $\mathbf{5}$ & $\begin{array}{l}\text { Menerapkan } \\
\text { Konsep }\end{array}$ & 1,7 & 59 & 1,7 & 59 \\
\hline & Rata-rata & $\mathbf{1 , 8}$ & $\mathbf{6 2}$ & $\mathbf{1 , 8}$ & $\mathbf{6 2}$ \\
\hline
\end{tabular}

Berdasarkan tabel 2 di atas menunjukkan rata-rata keterampilan proses sains. Untuk rata-rata keseluruhan padasaat posttest $\mathrm{di}$ kelas eksperimen terhitung 1,8 .

Rata-rata tersebut juga sama dengan kelas kontrol yaitu 1,8 . Sehingga rata-rata keterampilan proses sains setelah siswa mengerjakan tes uraian berdasarkan indikator KPS adalah sama.

Setelah didapat hasil pretest-postest anatara kelas eksperimen dan kelas kontrol, maka dicari nilai $\mathrm{N}$-gain untuk mengetahui peningkatan keterampilan proses sains siswa. Perhitungan tersebut diperoleh dari nilai pretest dan posttest masing-masing kelasyaitu kelas eksperimen dan kelas kontrol. Hasil peningkatan tersebut dapat dilihat pada tabel 3 di bawah ini :

Tabel 3.Data Skor Pre Test dan Postes berdasarkan perhitungan N-Gain

\begin{tabular}{ccccc}
\hline Kelas & $\begin{array}{c}\text { SkorPre } \\
\text {-Test }\end{array}$ & $\begin{array}{c}\text { Skor } \\
\text { Post-Tes }\end{array}$ & $\begin{array}{c}\text { Rata-rata } \\
\text { N Gain }\end{array}$ & Kriteria \\
\hline Eksperimen & 526,2 & 515,9 & 0,4 & Sedang \\
\hline Kontrol & 774,9 & 792,4 & 0,4 & Sedang \\
\hline
\end{tabular}

Berdasarkan tabel 3 di atas dapat dilihat pada skor pretes menuju skor postest mengalami kenaikan dari kedua kelompok sampel. Hal tersebut dapat disimpulkan bahwa baik dari kelompok kelas eksperimen dan kelompok kelas kontrol mengalami peningkatan. Namun, kedua kelompok sampel mengalami peningkatan yang sama yaitu hasil perhitungan $\mathrm{N}$-Gain terhitung 0,4 dengan kriteria yang sedang.

Berdasarkan perhitungan program software IBM SPSS (Statistical Product and Service Solution) 16 for Windows, pengujian gain yang ternormalisasi dapat dilihat pada tabel 4 .
Tabel 4.Data Normalitas N- GainKelas Eksperimen dan Kontrol UjiNormalitas

\begin{tabular}{cccc}
\hline Kelas & $\begin{array}{c}\text { Jumlah } \\
\text { Siswa }\end{array}$ & $\begin{array}{c}\text { Tingkat } \\
\text { Signifikasi }\end{array}$ & Keterangan \\
\hline Eksperimen & 36 & $0,006<0,05$ & TidakNormal \\
\hline Kontrol & 36 & $0,42<0,05$ & TidakNormal
\end{tabular}

Dikarenakan uji normalitas data N-Gain antara kedua kelompok yang tidak berdistribusi normal, maka pengujian selanjutnya dilakukan uji Mann Whitney. Hasil uji kesamaan rata-rata dapat dilihat berdasarkan tabel 5 di bawah ini :

Tabel 5.Data Hasil Kesamaan Rata-rata KelasEksperimen dan Kontrol Uji Statistik (Mann Whitney)

\begin{tabular}{cc}
\hline Tingkat Signifikasi & Keterangan \\
\hline $0,284 \geq 0,05$ & $\mathrm{H}_{\mathrm{O}}$ diterima \\
\hline
\end{tabular}

Berdasarkan data statistik pengujian NGain melalui Mann Whitney, hasil pertitungannya yaitu 0,284 . Hal tersebut menyimpulkan pula tidak terdapat perbedaan peningkatan KPS yang signifikan antara kelas eksprimen yang menerapkan model Modified Free Inquiry(MFI) dan kelas kontrol yang menerapkan model Group Investigation (GI) dengan metode yang sama yakni metode praktikum.

\section{Rekapitulasi Persentase Keterampilan} Proses Sains Siswa saat Praktikum

Keterampilan proses sains dinilai pada saat siswa melaksanakan praktikum di laboratorium. Rubrik penilaian yang telah dibuat untuk mengetahui sejauh mana 
keterampilan proses sains siswadalam pembelajaran Biologi untuk mengukur kegiatan praktikum siswa, khususnya materi Animalia berdasarkan indikator Keterampilan Proses Sains (KPS).
Indikator tersebut meliputi keterampilan siswa dalam mengamati, mengklasifikasi, berkomunikasi, berhipotesis dan menerapkan konsep/prinsip. Persentase Keterampilan Proses Sains Siswa dapat dilihat pada tabel 6 di bawah ini :

Tabel 6.Persentase Keterampilan Proses Sains SiswaKelas Eksperimen dan Kontrol

\begin{tabular}{|c|c|c|c|c|c|c|c|}
\hline \multirow{2}{*}{ No } & \multirow{2}{*}{ Indikator KPS } & \multirow{2}{*}{$\begin{array}{c}\text { Skor } \\
\text { Rata-rata }\end{array}$} & \multicolumn{2}{|c|}{ Kelas Eksperimen } & \multirow{2}{*}{$\begin{array}{c}\text { Skor } \\
\text { Rata-Rata }\end{array}$} & \multicolumn{2}{|c|}{ Kelas Kontrol } \\
\hline & & & Persentase & Kategori & & Persentase & Kategori \\
\hline 1 & Mengamati & 2,0 & $70 \%$ & Kompeten & 1,7 & $68 \%$ & Kompeten \\
\hline 2 & Mengklasifikasi & 1,7 & $61 \%$ & Kompeten & 1,3 & $46 \%$ & Perbaikan \\
\hline 3 & Berkomunikasi & 1,8 & $63 \%$ & Kompeten & 1,6 & $56 \%$ & Kompeten \\
\hline 4 & Berhipotesis & 1,6 & $56 \%$ & Kompeten & 1,9 & $66 \%$ & Kompeten \\
\hline 5 & $\begin{array}{l}\text { Menerapkan } \\
\text { Konsep }\end{array}$ & 1,7 & $59 \%$ & Kompeten & 1,6 & $57 \%$ & Kompeten \\
\hline & Rata-rata & 1,8 & $61,8 \%$ & Kompeten & 1,6 & $57,2 \%$ & Kompeten \\
\hline
\end{tabular}

Berdasarkan tabel 6 di atas, terdapat lima indikator Keterampilam Proses Sains (KPS) yaitu mengamati, mengklasifikasi, berkomunikasi, berhipotesis dan menerapkan konsep/prinsip. Siswa yang melaksanakan praktikum sejumlah 35 orang di kelas eksperimen dan 35 orang di kelas kontrol. Dapat dilihat jika rata-rata indikator di kelas eksperimen dengan di kelas kontrol memiliki persestase yaitu $61,8 \%$ di kelas eksperimen dan $57,2 \%$ di kelas kontrol.

Berdasarkan gambar 1 di atas, terlihat bahwa persentase rata-rata di setiap indikator antara kelas eksperimen dengan kelas kontrol jika presentase yang lebih tinggi didominasi oleh kelas eksperimen.

Pada keterampilan mengamati, mengklasifikasi, berkomunikasi dan menerapkan konsep lebih tinggi di kelas eksperimen, sedangkan di kelas kontrol lebih tinggi hanya pada keterampilan berhipotesis.
Analisis
Lembar
Observasi

Pembelajaran menggunakan Model Modified Free Inquiry dengan Metode Observasi.

Lembar observasi digunakan untuk mengetahui keterlaksanaan model yang diterapkan oleh peneliti di kelas eksperimen. Lembar observasi ini dinilai oleh seorang observer dalam melihat keberlangsungan pembelajaran di awal pelajaran sampai akhir pelajaran. Lembar observasi memuat aktivitas guru yang terdiri dari kegiatan awal, kegiatan inti dan kegiatan penutup. Dapat dilihat pada tabel 7 dibawah ini :

Tabel 7.Analisis Lembar Observasi menggunakan model Modified Free Inquiry

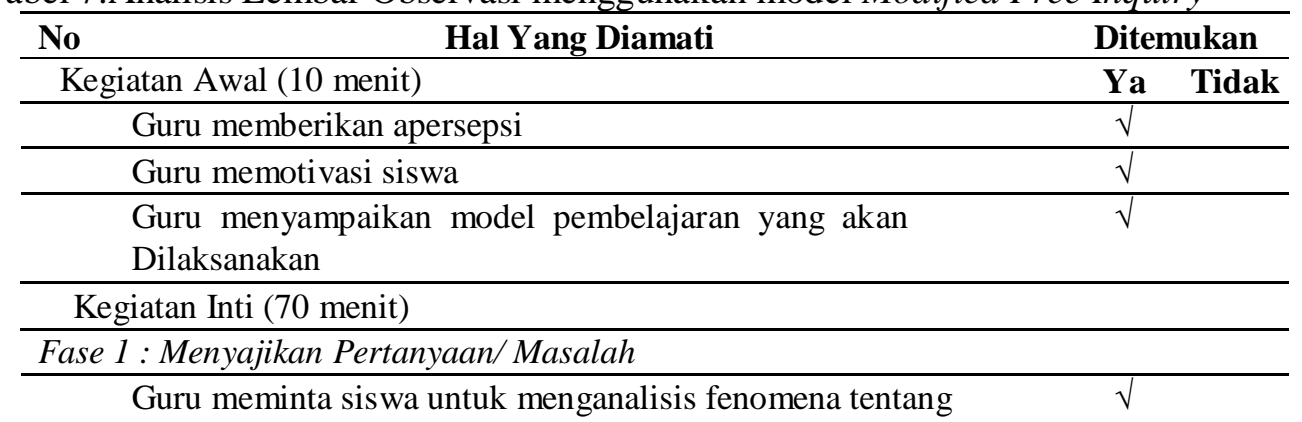


hewan invertebrata

\begin{tabular}{cll}
\hline Guru memfasilitasi & siswa dengan memberikan panduan & $\sqrt{ }$ \\
\hline
\end{tabular}

\begin{tabular}{|c|c|c|}
\hline \multirow{2}{*}{\multicolumn{3}{|c|}{ Hat Laty Diatiat }} \\
\hline & & \\
\hline & Guru memintasiswauntukmembuatrumusanmasalah & $\sqrt{ }$ \\
\hline \multicolumn{3}{|c|}{ Fase 2 : MerancangHipotesis } \\
\hline & Guru memintasiswauntukmembuathipotesisberdasarkananalisis & $\sqrt{ }$ \\
\hline \multicolumn{3}{|c|}{ Fase 3 : MerancangPercobaan } \\
\hline \multicolumn{3}{|c|}{ Fase 4 : MelakukanPercobaanuntukMemperolehInformasi } \\
\hline & $\begin{array}{l}\text { Guru } \\
\text { memberikesempatankepadasiswasecaramandiriuntukmelaksanakanpraktikum }\end{array}$ & $\sqrt{ }$ \\
\hline \multicolumn{3}{|c|}{ Fase 5 : MengumpulkandanMenganalisis Data } \\
\hline & $\begin{array}{l}\text { Guru } \\
\text { memfasilitasisiswauntukmempresentasikanhasilkerjakelompokdidepankelas }\end{array}$ & $\sqrt{ }$ \\
\hline \multicolumn{3}{|c|}{ Fase 6: MembuatKesimpulan } \\
\hline & Guru memberikesempatankepadasiswauntukmenyimpulkanhasildiskusi & $\sqrt{ }$ \\
\hline \multicolumn{3}{|c|}{ Kegiatanpenutup (10 menit) } \\
\hline & $\begin{array}{l}\text { Guru memintasiswauntukmenarikkesimpulankembalidarimateri } \\
\text { telahdisampaikan }\end{array}$ & $\sqrt{ }$ \\
\hline
\end{tabular}

Berdasarkan tabel 7 diatas hasil penilaian observer menganai keterlaksanaan model yang diterapkan dikelas eksperimen selama proses pembelajaran (selama siswa praktikum) yaitu guru dapat memulai kegiatan awal pembelajaran, kegiatan inti dan kegiatan penutup dengan persentase $100 \%$. Haltersebut berarti keterlaksanaan pembelajaran dilaksanakan dengan sangat baik.

\section{Pembahasan}

\section{Analisis Keterampilan Proses Sains}

Keterampilan proses sains yang dianalisis pada saat siswa melaksanakan tes uraian mengenai indikator keterampilan proses sains yaitu keterampilan mengamati, mengklasifikasi, berkomunikasi, berhipotesis dan menerapkan konsep/prinsip.Rata-rata perhitungan prestest di kelas eksperimen memiliki rata-rata tertinggi yaitu pada indikator menerapkan prinsip/konsep yaitu 1,3 sedangkan di kelas kontrol memiliki ratarata tertinggi pada indikator menerapkan konsep/prinsip yang terhitung 1,2. Rata-rata perhitungan terendah di kelas eksperimen terhitung 0,8 yaitu pada indikator mengklasifikasi sedangkan di kelas kontrol pun sama pada indikator mengklasifikasi yang terhitung 0,7 . Rata-rata perhitungan saat posttest rata-rata tertinggi di kelas eksperimen pada indikator mengamati yaitu 2,0 sedangkan di kelas kontrol rata-rata terhitung 2,0 dengan indikator yang sama yaitu mengamati.

Dari hasil perhitungan rata-rata keterampilan proses sains, menunujukan peningkatan KPS dari prestest ke postest yaitu di kelas eksperimen terhitung mengalami peningkatan 1,06 ke 1,8 sedangkan di kelas kontrol terhitung mengalami peningkatan 0,92 ke 1,8. Dari hasil perhitungan tersebut menunjukkan hasil peningkatan yang tidak jauh beda antara kelas eksperimen dan kelas kontrol. Hal tersebut dikarenakan pencapaian pembelajaran yang harus dicapai siswa untuk mengidentifikasi, mengklasifikasi, menganalisis dan menjelaskan konsep tentang hewan itu sama antara kelas eksperimen dan kelas kontrol. Meskipun model yang diterapkan di masingmasing kelas berbeda, yaitu di kelas ekperimen siswa melaksanakan praktikum berbasis model Modified Free Inquiry dan di kelas kontrol siswa melaksanakan praktikum berbasis model kooperatif Group Investigation. Keduanya mempunyai kesamaan yaitu mengandung unsur penemuan dalam proses pembelajarannya. Hal tersebut menyimpulkan bahwa kelas eksperimen dan kelas kontrol memiliki taraf peningkatan yang sama dalam meningkatkan keterampilan proses sains siswa baik yang menggunakan 
Quagga: Jurnal Pendidikan dan Biologi Volume 10, Nomor 1, Januari 2018

model Modified Free Inquiry maupun Group Investigation.

Peningkatan keterampilan proses sains siswa juga dihitung berdasarkan perhitungan $\mathrm{N}$-Gain atau Gain yang ternormalisasi. Hasil rata-rata N- Gain di kelas eksperimen terhitung 0,4 dengan kategori sedang dan hasil rata-rata $\mathrm{N}$-Gain di kelas kontrol terhitung 0,4 dengan kategori sedang. Hasil rata-rata $\mathrm{N}$ - Gain baik di kelas eksperimen maupun di kelas kontrol terhitung sama yaitu 0,4 dengan kategori sedang. Hal ini membuktikan jika terdapat peningkatan dari pretest (tes awal) ke postest (tes akhir) baik di kelas eksperimen maupun di kelas kontrol.

Selain dihitung berdasarkan perhitungan $\mathrm{N}$-Gain, hasil rata-rata $\mathrm{N}$-Gain juga diuji prasyarat dengan uji kesamaan rata-rata (Mann Whitney) N-Gain kelas eksperimen dan kelas kontrol. Hasil pengujian tersebut juga menyatakan tidak terdapat perbedaan yang signifikan antara kelas eksprimen yang menerapkan model Modified Free Inquiry (MFI) dan kelas kontrol yang menerapkan model Group Investigation (GI) dengan metode yang sama yakni metode praktikum. Kesamaan tersebut telah dijelaskan pada pembahasan di paragraf sebelumnya bahwa menerapkan model pembelajaran Group Investigation (GI) dan Inquiry, keduanya mempunyai kesamaan yaitu mengandung unsur penemuan dalam proses pembelajarannya (Supriyadi \& Mawardi, 2015). Hal tersebut menyimpulkan bahwa kelas eksperimen dan kelas kontrol memiliki tarafpeningkatan yang sama dalam meningkatkan keterampilan proses sains siswa baik yang menggunakan model Modified Free Inquiry maupun Group Investigation.

Analisis Keterampilan Proses Sains Siswa saat Praktikum

Keterampilan proses sains berdasarkan model inkuiri yang diteliti saat siswa melakukan praktikum di laboratorium menuntut siswa untuk melakukan penyelidikan yang dibutuhkan dalam menghubungkan antar konsep dalam membangun pengetahuan. Kegiatan pembelajaran siswa di kelas eksperimen yang menuntut siswa untuk lebih diajak menguasai konsep sains oleh guru karena guru telah memfasilitasi siswa melakukan praktikum di
p-ISSN 1907-3089, e-ISSN 2651-5869

https://journal.uniku.ac.id/index.php/quagga

laboratorium dengan model inkuiri yang bebas termodifikasi atau Modified Free Inquiry.

Keterampilan Proses Sains Siswa dinilai berdasarkan lima indikator, yaitu keterampilan dalam mengamati hewan, mengklasifikasi hewan, berkomunikasi, berhipotesis dan menerapkan konsep/prinsip dalam praktikum hewan invertebrata. Berdasarkan penilaian dari guru, hasil KPS siswa di kelas eksperimen mendapat persentase rata-rata sebesar $61,8 \%$ dengan kategori yang kompeten. Rata-rata tiap indikatornya memiliki keunggulan jika dibandingkan dengan kelas kontrol. Di kelas eksperimen, indikator dalam hal mengamati hewan-hewan invertebrata memiliki persentase $70 \%$, indikator mengklasifikasi sebesar $61 \%$, indikator berkomunikasi sebesar $63 \%$, indikator berhipotsesis sebesar 56\% dan indikator menerapkan konsep/prinsip sebesar $59 \%$. Berbeda dengan persentase rata-rata di kelas kontrol yakni sebesar $57,2 \%$. Di kelas kontrol, indikator dalam hal mengamati hewan-hewan invertebrata memiliki persentase $68 \%$, indikator mengklasifikasi sebesar $46 \%$, indikator berkomunikasi sebesar $56 \%$, indikator berhipotesis sebesar $66 \%$ dan indikator menerapkan konsep/prinsip sebesar $57 \%$.

Hasil rata-rata penilaian KPS siswa di kelas eksperimen mendapat persentase ratarata sebesar 61,8\% dengan kategori yang kompeten dan hasil rata-rata penilaian KPS siswa di kelas kontrol mendapat persentase rata-rata sebesar 57,2 \%. Hal tersebut menyimpulkan jika persentase untuk penilaian KPS siswa, kelas eksperimen lebih tinggi dalam menguasai keterampilan proses sains dengan diterapkannya model Modified Free Inquiry. Pembelajaran model MFI berbasis praktikum, siswa lebih diarahkan pada eksperimental learning (belajar berdasarkan pengalaman konkret), diskusi dengan teman, yang selanjutnya akan diperoleh ide dan konsep baru (Hayat dan Anggraeni, 2011: 143) dalam Lilis et al. (2015:66). Sehingga dalam melakukan penyelidikannya, siswa di kelas eksperimen memiliki keterampilan proses sains yang lebih tinggi jika dibandingkan dengan kelas kontrol. Keterampilan proses sains siswa dalam berinkuiri jauh lebih tinggi jika 
Quagga: Jurnal Pendidikan dan Biologi Volume 10, Nomor 1, Januari 2018

dibandingkan dengan kelas kontrol yang menerapkan model GroupInvestigation.

\section{Analisis Lembar Observasi}

Lembar observasi digunakan untuk mengetahui keterlaksanaan model yang diterapkan oleh peneliti di kelas eksperimen. Lembar observasi ini dinilai oleh seorang observer dalam melihat keberlangsungan pembelajaran di awal pelajaran sampai akhir pelajaran. Lembar observasi memuat aktivitas guru yang terdiri dari kegiatan awal, kegiatan inti dan kegiatan penutup.

Kegiatan awal berlangsung selama 10 menit yang terdiri dari aktivitas guru dalam menyampaikan tujuan pembelajaran yang harus siswa capai pada proses pembelajaran, memberikan apersepsi atau statement awal dalam mengarahkan siswa untuk melakukan praktikum hewan invertebrata, memotivasi siswa untuk melakukan praktikum dan yang terpenting adalah menyampaikan model pembelajaran Modified Free Inquiry. Dalam kegiatan awal guru dapat memulai awal pembelajaran dengan persentase $100 \%$ sehingga dapat dilaksanakan dengan baik.

Kegiatan inti berlangsung 70 menit memuat kegiatan guru yang menerapkan model Modified Free Inquiry (MFI) yang terdiri dari 6 fase yaitu menyajikan masalah, merancang hipotesis, merancang percobaan, melakukan percobaan, mengumpulkan atau menganalisis data, dan membuat kesimpulan. Persentase yang didapat pada kegiatan inti yaitu $100 \%$ yang berarti semua fase di setiap langkah model Modified Free Inquiry terlaksana, tetapibelum maksimal dalam merumuskan masalah dan hipotesisi. Hal tersebut dikarenakan dalam mengkaji permasalahan siswa belum maksimal dalam mengkaji fenomena unik hewan invertebrata, dan siswa masih diarahkan dan dibimbing dalam mengkaji permasalahan oleh guru, sehingga kemampuan siswa dalam keterampilan berhipotesis belum terlaksana secara maksimal.

Kegitan akhir yang berlangsung selama 10 menit guru memberikan reward kepada kelompok yang memiliki skor tertinggi saat kegiatan prsesentasi berlangsung, guru meminta siswa untuk menarik kesimpulan kembali dari materi yang telah disampaikan, guru meminta siswa untuk mengerjakan soalsoal mengenai ciri-ciri hewan invertebrata,
p-ISSN 1907-3089, e-ISSN 2651-5869

https://journal.uniku.ac.id/index.php/quagga

guru mengakhiri kegiatan belajar dengan memberikan motivasi kepada semua siswa untuk lebih aktif dalam kegiatan diskusiagar pembelajaran lebih terkesan menyenangkan dan terlaksananya tujuan pembelajaran, serta guru memberi salam penutup kepada seluruh siswa. Kegiatan akhir persentase yang didapat adalah $100 \%$ karena guru dapat menutup pembelajaran dengan baik hingga guru memberikan reward (penghargaan).

\section{KESIMPULAN}

Berdasarkan hasil penelitian dan analisis data hasil penelitian yang dilakukan maka kesimpulan dari hasil uji hipotesis yang didapat dari hasil perhitungan N-Gain, jika hasil peningkatan dari pretes ke postest mengalami peningkatan yaitu 0,4 dengan kategori sedang, yang berarti metode praktikum berbasis Modified Free Inquiry dapat meningkatkan keterampilan proses sains siswa kelas $\mathrm{X}$ MIPA. Hasil keterampilan proses sains untuk menilai kemampuan siswa dalam mengamati, mengklasifikasi, berkomunikasi, berhipotesis dan menerapkan konsep selama praktikum, siswa kelas eksperimen menerapkan model Modified Free Inquiry, memiliki persentase yang lebih tinggi dibandingkan dengan kelas kontrol yaitu sebesar $61,8 \%$ dengan kategori kompeten.

\section{REFERENSI}

Kurniawati, Lilis, Reza A.O \& Muh. Ali Misri. 2015. Pengaruh Penerapan Metode Pembelajaran Praktikum terhadap Keterampilan Berpikir Kritis Matematika Siswa Kelas Viii Smp N 3Sumber Kabupaten Cirebon. (Online) Tersedia : http://www. syekhnurjati.ac.id/jurnal/i ndex.php/eduma/article/view/30/28 (diakses tanggal 16 Januari 2017) Hal: 66

Rustaman, Nuryani Y, dkk. 2005. Strategi Belajar Mengajar Biologi. Malang: Universitas Negeri Malang

Sartika, Septi Budi. 2015. Analisis Keterampilan Proses Sains (KPS) Mahasiswa Calon Guru dalam Menyelesaikan Soal IPA Terpadu (Online). Prosiding Seminar Nasional Pendidikan. 
Quagga: Jurnal Pendidikan dan Biologi Volume 10, Nomor 1, Januari 2018

Tersedia:http://journal.umsida.ac.id/fi les/4Sep ti.pdf. (diakses tanggal 11 Januari 2017) Hal : 1

Sugiyono. 2015. Metode Penelitian Pendidikan Pendekatan Kuantitatif, Kualitatif dan $R \& D$. Bandung: Alfabeta

Supriyadi \& Mawardi. 2015. Keefektifan Model Pembelajaran Kooperatif Tipe Group Investigation (GI) Dan Inquiry dalam Pembelajaran IPAKelas VIII SMP (Online) diakses tanggal $21 \mathrm{Mei}$ 2017)
p-ISSN 1907-3089, e-ISSN 2651-5869

https://journal.uniku.ac.id/index.php/quagga 